Received : 2021-04-14 Revised : 2021-06-08 Acceptance : 2021-06-08 Publish : 2021-06-17

\title{
WASTE SEPARATION TREATMENT AND INFORMATION EXPOSURE TO HOUSEHOLD WOMEN IN PELANTAR OF TANJUNGPINANG CITY, INDONESIA
}

\author{
Hengky Oktarizal ${ }^{1,2 *}$, Novita Sari ${ }^{3}$, Elsusi Martha ${ }^{4}$ \\ ${ }^{* 1}$ Faculty of Health Sciences, Universitas Ibnu Sina, Jalan Teuku Umar, Lubuk Baja 29444 \\ Batam City, Riau Islands, Indonesia \\ *22 Doctoral Degree Program of Environmental Science, Universitas Sriwijaya, Jalan Padang \\ Selasa No.524, Bukit Lama 30319, Kec.Ilir Bar. I, Palembang City, South Sumatra, Indonesia \\ ${ }^{3}$ Faculty of Health Sciences, Universitas Ibnu Sina, Jalan Teuku Umar, Lubuk Baja 29444 \\ Batam City, Riau Islands, Indonesia \\ ${ }^{4}$ Faculty of Health Sciences, Universitas Ibnu Sina, Jalan Teuku Umar, Lubuk Baja 29444 \\ Batam City, Riau Islands, Indonesia \\ *Email: hengky.oktarizal@uis.ac.id
}

\begin{abstract}
Pelantar of Tanjungpinang City is a densely populated area and the center of the community's economy where attention to household waste management has not been carried out according to requirements. Housewives still process the waste that is not in accordance with the classification of waste types. The information obtained from the government is still deemed inadequate. The study aimed to explain the relationship between the treatment of waste management and information exposure to housewives in Pelantar of Tanjungpinang City. This research method was categorized as an analytic observational study with a cross sectional approach. The number of population was 964 people and the number of sample was 91 people using purposive sampling technique, namely the housewives in Pelantar of Tanjungpinang City. The hypothesis testing used the Chi Square test. The results of this study showed that there was no relationship between the public knowledge $(0.063)$ and the household waste management. There was a relationship between the community attitudes (0.003) and the household waste management. There was a relationship between the community action $(0.000)$ and the household waste management. There was a relationship between the information sources (0.002) and the household waste management in Pelantar of Tanjungpinang City. This research concludes that there were three variables related to the household waste management, namely attitudes, actions and sources of information. It is suggested that the Tanjungpinang City Administration collaborate with crosssectoral efforts to increase socialization and education regarding the household waste management, and the community reduce the waste piles and implement the $5 \mathrm{R}$ reduce, reuse, recycle, replace and respect. Keywords : Pelantar of Tanjungpinang City, Waste type classification, Housewives
\end{abstract}




\section{INTRODUCTION}

Pelantar is a densely populated area and the center of the community's economy in Tanjungpinang City. This becomes the government's attention to the problem of solid waste, in which the household waste produces as much as 28.00 ton/day ${ }^{1}$. Public awareness of waste management is still low, especially for people living in abandoned areas where large amounts of waste are found ${ }^{2}$. Waste is a serious threat because it can cause social, economic and cultural problems ${ }^{3}$. This obstacle exists in almost all cities in Indonesia, especially in waste management ${ }^{4}$. Proper household waste management can help reduce the negative impact of waste on the environment ${ }^{5}$.

Public awareness in waste management is needed to minimize the impact caused by the negative impact of waste ${ }^{7}$. Indonesia is estimated to produce 67.8 million tons of waste every year and will continue to grow as the population grows ${ }^{8}$. The composition of waste is dominated by organic waste reaching $60 \%$ of the total waste. The national waste generation in 2019 was 175,000 ton/day if it was assumed that the waste produced by each person per day was $0.7 \mathrm{~kg}{ }^{9}$. Riau Islands Province produces waste reaching 1422.87 ton/day. Tanjungpinang is one of the regions with the highest waste generation, amounting to 168.00 ton/day, with a total of 125.00 ton/day of household waste generation ${ }^{10}$.

Sorting household waste occurs in Japan and Sweden, and the Netherlands. Every household in Japan cannot just put all their waste in one bag because they have to put it in a separate bag, some even require that the trash be put into a transparent bag. Sweden has a sophisticated waste processing system, waste management with the concept of waste-to-energy (WTE) ${ }^{11}$.

Information regarding household waste management for KUD (Village Unit Cooperative) community of Pelantar is not yet fully understood by the surrounding community, in which the residents get this information through an appeal from the City Administration that directly invites them to reduce waste generation, especially in reducing the amount of household waste.

\section{MATERIAL AND METHOD}

\section{Population and Sample}

An interesting aspect of this study is its focus on the capital of the Riau Islands Province. The city is estimated to accommodate almost a quarter of the population ${ }^{12}$. Pelantar of Tanjungpinang City is a densely populated area and economic center of the community as well as a port area ${ }^{13}$. The population in this study was the housewives in Pelantar of Tanjungpinang City amounting to 964 people and the number of sample was 91 people.

\section{Research Type}

Quantitative research method can be defined as a research method based on the philosophy of positivism used to research on a particular population or sample ${ }^{14}$. The research sample is analytic observational with a cross sectional approach which is one of the research designs or it can also be seen as a social research methodology ${ }^{15}$. The survey was conducted from May to August 2020.

\section{Sampling Technique}

The sampling technique used non-random (non-probability) sampling, a sample selection technique that was not based on the law of probability and therefore did not require an equal opportunity for members of the population to be selected, the selection was based on certain subjective criteria, but the 
criteria should be kept clear so as not to cause bias ${ }^{16}$. The sampling technique used purposive sampling, namely the housewives based on the heads of the families in Pelantar of Tanjungpinang City. The purposive sampling technique was intentionally defined by the researchers, which was not purely based on the investigators' subjective criteria, but was based on a specific purpose (purposive) and judgments ${ }^{17}$.

\section{Data Collection and Analysis}

The approach to the data processing was carried out through statistical or mathematical methods collected from the secondary data. This was done to see more measured and comprehensive conclusion, while the data analysis in this research used statistically correlational techniques.

\section{RESULTS AND DISCUSSION}

\section{a. Analysis of the Relationship between Knowledge and Household Waste Management}

The proportion of the level of public knowledge about household waste management could be said to be good, namely as many as 23 people. Based on the results of the Pearson Chi Square test, the p-value was 0.063 , it was much greater than the value of $a 0.05$ (Ho was accepted). Thus it is concluded that there was no relationship between the public knowledge and the household waste management in KUD of Pelantar of Tanjungpinang City (Table 1).

Table 1

The Relationship between Community Knowledge and Household Waste Management in Pelantar of Tanjungpinang City

\begin{tabular}{cccccccccc} 
& \multicolumn{1}{c}{ Household Waste Management } & \multirow{2}{*}{ Knowledge } & \multicolumn{3}{c}{ Good } & \multicolumn{3}{c}{ Sufficient } & \multicolumn{2}{c}{ Deficient } & \multicolumn{2}{c}{ Total } & \multirow{2}{*}{ Value } \\
\cline { 2 - 9 } & $\mathbf{N}$ & $\mathbf{\%}$ & $\mathbf{n}$ & $\mathbf{\%}$ & $\mathbf{n}$ & $\mathbf{\%}$ & $\mathbf{N}$ & $\mathbf{\%}$ & \\
\hline Good & 15 & 34,1 & 23 & 52,3 & 6 & 13,6 & 44 & 100 & \\
\hline Sufficient & 8 & 42,1 & 11 & 57,9 & 0 & 0 & 19 & 100 & \multirow{2}{*}{0.063} \\
\hline Deficient & 7 & 25 & 21 & 75 & 0 & 0 & 28 & 100 & \\
\hline Amount & $\mathbf{3 0}$ & $\mathbf{3 3}$ & $\mathbf{5 5}$ & $\mathbf{6 0 . 4}$ & $\mathbf{6}$ & $\mathbf{6 . 6}$ & $\mathbf{9 1}$ & $\mathbf{1 0 0}$ &
\end{tabular}

\section{b. Analysis of the Relationship between Attitudes and Household Waste Management}

The proportion of the level of community attitudes towards the household waste management was good, namely as many as 30 people. Based on the results of the Pearson Chi Square test, the p-value was 0.003 , this result was much smaller than the value of 0.05 (Ho was rejected). In conclusion, there was a relationship between the community attitude and the household waste management in Pelantar of Tanjungpinang City (Table 2). 
Table 2

The Relationship between Community Attitudes and Household Waste Management in Pelantar of Tanjungpinang City

\begin{tabular}{|c|c|c|c|c|c|c|c|c|c|}
\hline \multirow{3}{*}{ Attitudes } & \multicolumn{8}{|c|}{ Household Waste Management } & \multirow{3}{*}{ Value } \\
\hline & \multicolumn{2}{|c|}{ Good } & \multicolumn{2}{|c|}{ Sufficient } & \multicolumn{2}{|c|}{ Deficient } & \multicolumn{2}{|c|}{ Total } & \\
\hline & $\mathbf{n}$ & $\%$ & $\mathbf{n}$ & $\%$ & $\mathbf{N}$ & $\%$ & $\mathbf{N}$ & $\%$ & \\
\hline Good & 30 & 49,2 & 30 & 49,2 & 1 & 1,6 & 61 & 100 & \multirow{4}{*}{0.003} \\
\hline Sufficient & 0 & 0 & 24 & 82,8 & 5 & 17,2 & 29 & 100 & \\
\hline Deficient & 0 & 0 & 1 & 100 & 0 & 0,0 & 1 & 100 & \\
\hline Amount & 30 & 33 & 55 & 60.4 & 6 & 6.6 & 91 & 100 & \\
\hline
\end{tabular}

\section{c. Analysis of the Relationship between Actions and Household Waste Management}

The proportion of the level of action on the management of household waste was fair, namely as many as 39 people. The test result of Pearson Chi Square showed that the p-value was 0.000 , this result was much smaller than the value of 0.05 (Ho was rejected). In conclusion, there was a relationship between the community actions and the household waste management in KUD of Pelantar of Tanjungpinang City (Table 3).

Table 3

The Relationship between Community Action and Household Waste Management in Pelantar of Tanjungpinang City

\begin{tabular}{|c|c|c|c|c|c|c|c|c|c|}
\hline \multirow{3}{*}{ Action } & \multicolumn{8}{|c|}{ Household Waste Management } & \multirow{3}{*}{ Value } \\
\hline & \multicolumn{2}{|c|}{ Good } & \multicolumn{2}{|c|}{ Sufficient } & \multicolumn{2}{|c|}{ Deficient } & \multicolumn{2}{|c|}{ Total } & \\
\hline & $\mathbf{n}$ & $\%$ & $\mathbf{n}$ & $\%$ & $\mathbf{n}$ & $\%$ & $\mathbf{N}$ & $\%$ & \\
\hline Good & 29 & 74,4 & 10 & 25,6 & 0 & 0,0 & 39 & 100 & \multirow{4}{*}{0.000} \\
\hline Sufficient & 1 & 2,4 & 39 & 95,1 & 1 & 2,4 & 41 & 100 & \\
\hline Deficient & 0 & 0,0 & 6 & 54,5 & 5 & 45,5 & 11 & 100 & \\
\hline Amount & 30 & 33 & 55 & 60.4 & 6 & 6.6 & 91 & 100 & \\
\hline
\end{tabular}

\section{d. Analysis of the Relationship between Information Sources and Household Waste Management}

The proportion of information sources on the household waste management was fair, namely as many as 39 people. The result of the Pearson Chi Square test showed that the p-value was 0.002 , this result was much smaller than the value of 0.05 (Ho was rejected). In conclusion, there was a relationship between the sources of information and the household waste management in KUD of Pelantar of Tanjungpinang City in 2020 (Table 4). 
Table 4

The Relationship between Information Sources and Household Waste Management in Pelantar of Tanjungpinang City

\begin{tabular}{|c|c|c|c|c|c|c|c|c|c|}
\hline \multirow{3}{*}{$\begin{array}{c}\text { Information } \\
\text { Sources }\end{array}$} & \multicolumn{8}{|c|}{ Household Waste Management } & \multirow{3}{*}{ Value } \\
\hline & \multicolumn{2}{|c|}{ Good } & \multicolumn{2}{|c|}{ Sufficient } & \multicolumn{2}{|c|}{ Deficient } & \multicolumn{2}{|c|}{ Total } & \\
\hline & $\mathbf{n}$ & $\%$ & $\mathbf{n}$ & $\%$ & $\mathbf{n}$ & $\%$ & $\mathbf{N}$ & $\%$ & \\
\hline Good & 17 & 68,0 & 8 & 32,0 & 0 & 0,0 & 25 & 100 & \multirow{4}{*}{0.002} \\
\hline Sufficient & 8 & 17,0 & 39 & 83,0 & 0 & 0,0 & 47 & 100 & \\
\hline Deficient & 5 & 26,3 & 8 & 42,1 & 6 & 31,6 & 19 & 100 & \\
\hline Amount & 30 & 33 & 55 & 60.4 & 6 & 6.6 & 91 & 100 & \\
\hline
\end{tabular}

\section{The relationship between community knowledge and household waste management}

Based on the research results using the Chi Square test, the Asymp value. Sig. (2-Sided) on the Pearson Chi Square test was 0.063. Due to the Asymp value. Sig. (2-Sided) 0.063>0.05, it concluded that Ho was accepted and Ha was rejected. Consequently, there was no relationship between the knowledge of housewives and the household waste management in Pelantar of Tanjungpinang City in 2020. In other words, better knowledge does not mean better household waste management and vice versa, lower knowledge does not mean lower level of household waste management. Knowledge is an important domain in the formation of open behavior ${ }^{18}$. Knowledge of an object is divided into two aspects, namely positive aspects and negative aspects. These two aspects will determine how a person behaves. The more dominant the known positive aspects and objects will lead to a more positive attitude towards certain objects ${ }^{19}$. Most of the Pelantar people of Tanjungpinang City have good knowledge about waste management, this knowledge is obtained from some good information from the Tanjungpinang City Administration, health workers (Kampung Bugis Public Health Center) and information from various media, but in fact not all of them understood and carried out household waste management such as not using styreofoam and plastic to wrap food. Plastics and styreofoam are very difficult to avoid considering Pelantar is a traditional market in Tanjungpinang City, whose residents mostly traders and fishermen. The study conducted by Rohmatin, Lampus and Tucunan shows that there is no relationship between the level of knowledge and household waste management in the neighborhood II of Kelurahan Sumompo of Tuminting Subdistrict, Manado City. This is due to the respondents who are good in knowledge but poor in waste management; the respondents who have less knowledge, some of them have good waste management. Furthermore, according to the study of Srisantyorini and Ningtyas there is no relationship between the knowledge and the waste management behavior; however, the obtained data showed that respondents with good knowledge had a tendency to carry out waste management behavior compared to those with fair and less knowledge. The high knowledge of the housewives of Pelantar of Tanjungpinang City did not yet determine the management of household waste, in which the people were found to have high knowledge but low in household waste management, particularly the use of plastic to wrap food, whereas the plastic and styreoform rubbish is the 
materials difficult to decompose. This shows that public knowledge has not been able to drive the community in waste management.

\section{The relationship between community attitudes and household waste management}

Based on the study results using the Chi Square test, the Asymp value. Sig. (2-Sided) was 0.000. Because the Asymp value. Sig. (2-Sided) was $0.003<0.05$, the Ho was rejected and Ha was accepted. Therefore, there was a relationship between the attitude of housewives and the household waste management in Pelantar of Tanjungpinang City in 2020. In other words, the better the attitude is, the better the household waste management and vice versa, the lower the attitude is, the lower the household waste management. Attitude is defined as the reaction or response of someone who is still closed to a stimulus or an object. Attitude clearly shows the connotation of a person's reaction to certain stimuli, which in everyday life is an emotional reaction to social stimuli. Furthermore, the attitude is also a readiness or willingness to act, and not an implementation of a particular motive. The attitude function is not necessarily an action (open reaction) or someone's activity, but it is a predisposition to behavior (action) or closed reactions ${ }^{20}$. The research results showed that people having a good attitude towards the household waste management had a tendency in waste management, where most people strongly agreed that every house needed to have waste sorting to make it easier in household waste management, and they also considered that waste had to be put in its place in order not to have consequences from the waste that was not properly managed or not dumped in its place (littering). This shows that a good community attitude towards the household waste management will give a tendency to act in carrying out household waste management in Pelantar of Tanjungpinang City. This is in accordance with the study conducted by Rohmatin, Lampus and Tucunan that there is a relationship between attitudes and household waste management in the neighborhood II of Kelurahan Sumompo, Tuminting Subdistrict, Manado City. However, it is different from the study conducted by Sumah, Umboh and Akili showing that there is no relationship between attitudes and household waste management actions in the neighborhood II of Kelurahan Iatiqlal, Wenang Subdistrict, Manado City. Most of the Pelantar people agreed that every house had to have separation of waste, and reuse the goods that could still be used and considered that the waste in their area was their responsibility. They did not like to see people littering because it disturbed the comfort, cleanliness and health of the community's environment.

\section{The relationship between community actions and household waste management}

The results of the Chi Square test showed that the Asymp value. Sig. (2-Sided) was 0.000. Due to the Asymp value. Sig. (2-Sided) $0.000<0.05$, the Ho was rejected and Ha was accepted. In conclusion, there was a relationship between the actions of housewives and the household waste management in Pelantar of Tanjungpinang City in 2020. In other words, the better the action is, the better the household waste management and vice versa, the lower the action is, the 
lower the level of household waste management. The action is an attitude that does not necessarily manifest in an action (over behavior), to make an attitude into a real action, it needs supporting factors or enabling conditions, this condition is a facility ${ }^{20}$. The action consists of perception, namely recognizing and selecting objects in relation to actions, then guided response, doing things in the right order, then mechanisms, doing things correctly automatically and adaptation, which is a practice or action that is well developed. The results of the study showed that the people in Pelantar of Tanjungpinang City could still use inorganic waste such as bottles. Besides, they collected used cardboard to be used again as goods packages, especially people who work as traders, this is also included in the community action in household waste management. However, there were still people throwing their household waste in small alleys or at the intersection of the entrance to Pelantar. This is because the distance between the temporary garbage dumps was far from the residents' houses (Pelantar II). The study of Wildawati and Hasnita showed that there was a relationship between action and community-based household waste management in the area of Bank Sampah Hanasty. Most people in the Hanasty waste bank area, Kelurahan Tanah Garam, Lubuk Sikarah Subdistrict, Solok City had good actions in management waste. The community acted by sorting the organic and inorganic waste in their household environment. The household waste management must be carried out by the community in KUD of Pelantar. Real action is needed so that waste does not occur. The waste can be managed and used for daily needs and can be of economic value. The community did not implement the 5 Rs as a whole, namely Reduce, Reuse, Recycle, Replace and Respect. The people can use the 5 Rs for household waste management. It needs some movement from either the Government or health workers (Kampung Bugis Publich Health Center) for the community to apply the $5 \mathrm{Rs}$ in household waste management.

\section{The relationship between information sources and household waste management}

The results of the Chi Square test showed that the the Asymp value. Sig. (2-Sided) was is 0.000. Due to the Asymp value. Sig. (2-Sided) $0.002<0.05$, the Ho was rejected and Ha was accepted. In conclusion, there was a relationship between the sources of information and the household waste management in Pelantar of Tanjungpinang City in 2020. In other words, the better the sources of information are obtained, the better the management of household waste and vice versa, the lower the sources of information are obtained, the lower the management of household waste. Information sources are media that play an important role for a person in determining attitudes and decisions to act. Sources of information can be obtained freely ranging from peers, films, videos, books and even easily opening web pages via the internet, exposure to health information to individuals will be able to encourage health behavior. The results of the study showed that the housewives in Pelantar also received information from various sources such as printed media, television and even from health workers, in this case the Kampung Bugis Community Health Center. Sources of information do need to be provided on an ongoing basis so that people keep in mind the health impacts caused by waste generation in their area. According to the study of Setyowati and Mulasari, information can affect a person's knowledge 
so that the information sources can stimulate knowledge about plastic waste. Unlike the study of Srisantyorini and Ningtyas, there was no significant relationship between the information sources and the waste management behavior. Although the statistical test result showed there was no relationship between the information sources and the waste management behavior, the obtained data showed that the respondents exposed to the information sources had a tendency to carry out waste management behaviors compared to those not exposed to the information sources.

Sources of information obtained by the community regarding the household waste management were indeed obtained, from the various sources, including health workers, in this case the Kampung Bugis Community Health Center, in which the Pelantar area becomes the government's concern in terms of waste management, especially the household waste. In addition, the information sources are also obtained through other media such as printed media, television, internet sources and information from families.

\section{CONCLUSION}

The obtained research results conclude that the household waste management was categorized with enough category as many as $55(60.4 \%)$, good category as many as $30(33 \%)$ and poor as many as $6(6.6 \%)$. There was no relationship between public knowledge $(0.063)$ and household waste management in Pelantar of Tanjungpinang City. There was a relationship between community attitudes (0.003) and household waste management in Pelantar of Tanjungpinang City. There was a relationship between community actions (0.000) and the household waste management in Pelantar of Tanjungpinang City. There was a relationship between information sources (0.002) and household waste management in Pelantar of Tanjungpinang City.

\section{REFERENCES}

1. Hardiansyah, "Pengelolaan Bank Sampah di Kota Tanjungpinang," Tesis, 2013.

2. Sulisa, "Pengelolaan Sampah Berbasis Masyarakat di Wilayah Pesisir (Studi," Cybrarians J., 2015.

3. T. R. Johnson, "Municipal solid waste management," in Routledge Handbook of Environmental Policy in China, 2017.

4. S. Raharjo, T. Matsumoto, T. Ihsan, I. Rachman, and L. Gustin, "Community-based solid waste bank program for municipal solid waste management improvement in Indonesia: a case study of Padang city," J. Mater. Cycles Waste Manag., 2017, doi: 10.1007/s10163-0150401-z.

5. V. J. Inglezakis and K. Moustakas, "Household hazardous waste management: A review," Journal of Environmental Management. 2015, doi: 10.1016/j.jenvman.2014.11.021.

6. B. M. Menon, R. Unnikrishnan, A. Muir, and R. R. Bhavani, "Serious game on recognizing categories of waste, to support a zero waste recycling program," 2017, doi: 10.1109/SeGAH.2017.7939292.

7. J. Reno, "Waste and Waste Management," Annu. Rev. Anthropol., 2015, doi: 10.1146/annurev-anthro-102214-014146.

8. N. Anugrah, "KLHK: Indonesia Memasuki Era Baru Pengelolaan Sampah,” Klhk. 2020. 
9. H. Widowati, "Komposisi Sampah di Indonesia Didominasi Sampah Organik," Databoks.Katadata.Co.Id, 2019.

10. M. Hani and D. Prima Safitri, "Pengembangan Kapasitas Bank Sampah untuk Mereduksi Sampah di Kota Tanjungpinang," KEMUDI J. Ilmu Pemerintah., 2019, doi: 10.31629/kemudi.v4i1.1411.

11. D. Nainggolan, A. B. Pedersen, S. Smed, K. H. Zemo, B. Hasler, and M. Termansen, "Consumers in a Circular Economy: Economic Analysis of Household Waste Sorting Behaviour," Ecol. Econ., 2019, doi: 10.1016/j.ecolecon.2019.106402.

12. K. T. Pinang, "Profil Kabupaten / Kota Tanjung Pinang," 2018.

13. L. Prawiyanti, "Peranan Dinas Perumahan Rakyat, Kawasan Pemukiman, Kebersihan Dan Pertamanan Kota Tanjungpinang Dalam Mengatasi Sampah (Studi Kasus Di Pelantar, Kota Lama Tanjungpinang)," J. Soc. Polit., 2018.

14. P. D. Sugiyono, metode penelitian kuantitatif, kualitatif,dan R\&D. 2016.

15. Surahman, M. Rachmat, and S. Supardi, Metodologi Penelitian. 2016.

16. E. Prof. Dr. MS Barlian, Metodologi Penelitian Kualitatif \& Kuantitatif. 2016.

17. Sarmanu, Dasar Metodologi Penelitian Kuantitatif Kualitatif dan Statistika. 2017.

18. Syamsul Ahmad, Muzakkir, and Rosmini Rasimin, "Hubungan Pengetahuan Dan Pola Asuh Orang Tua Dengan Perilaku Merokok Pada Siswa Smk Mastar Makassar," J. Ilm. Kesehat. Diagnosis, 2020, doi: 10.35892/jikd.v15i1.343.

19. D. 2017 Notoatmodjo, 2014 dalam Kurnia, "Bab 2 Konsep Pengetahuan dan Sikap," eprints.umpo.ac.id, 2017.

20. Notoatmodjo, "Notoatmodjo," Pengetah. Sikap dan Perilaku, 2014. 